\title{
Physiological, morphological and growth responses to rhizosphere hypoxia by seedlings of North American bottomland oaks
}

\author{
ES Gardiner *, JD Hodges \\ Forest and Wildlife Research Center, Mississippi State University, Mississippi State, MS 36762, USA
}

(Received 2 November 1994; accepted 29 June 1995)

\begin{abstract}
Summary - Bottomland oak species of the southern United States are distributed along topographical gradients in floodplains. Because differences in soil aeration are associated with these gradients, we tested the hypothesis that oak species will exhibit diverging resistances to rhizosphere hypoxia. Four species which occupy different sites in floodplains, Quercus lyrata, $Q$ laurifolia, $Q$ phellos, and $Q$ nigra, were used in two experiments designed to examine seedling responses during establishment and late in the first growing season. In both experiments, hypoxia tolerance was evaluated through measurements of gas exchange, biomass accumulation, and shoot and root growth. Evidence of oaks differing in resistance to rhizosphere hypoxia is presented, and results are discussed in relation to species distribution in floodplains.
\end{abstract}

rhizosphere hypoxia / Quercus lyrata / Quercus laurifolia / Quercus phellos / Quercus nigra / ecophysiology

Résumé - Réponses physiologiques et morphologiques, et de croissance à l'hypoxie rhizosphérique de chênes des plaines inondables d'Amérique du Nord. Certaines espèces de chênes du sud des États-Unis sont distribuées le long de gradients topographiques dans les plaines inondables. Du fait des différences dans l'aération des sols associées à ces gradients, nous avons testé l'hypothèse que ces espèces présentent des résistances différentes à l'hypoxie rhizosphérique. Quatre espèces occupant différents sites des plaines inondables (Quercus lyrata, Q laurifolia, $Q$ phellos, et $Q$ nigra) ont été soumises à deux expérimentations pour évaluer les réponses des plantes au début et à la fin de la première saison. Dans les deux études, la tolérance à l'hypoxie a été estimée par la mesure d'échanges gazeux, l'accumulation de biomasse, et la croissance de la pousse et de la racine. Des différences de résistance à l'hypoxie de la rhizosphère ont été mises en évidence et les conséquences sur la distribution des espèces dans les plaines inondables ont été discutées.

rhizosphère / hypoxie / Quercus lyrata / Quercus laurifolia / Quercus phellos / Quercus nigra / écophysiologie

* Current address: Southern Hardwoods Laboratory, USDA, Forest Service, PO Box 227, Stoneville, MS 38776, USA 


\section{INTRODUCTION}

Microsite environments can profoundly influence the composition and dispersion of plants in communities. Soil surface heterogeneity, proximity to mature plants, leaf litter depth, and nutrient distributions are a few of the microsite attributes that can affect seed germination, establishment, and growth of herbaceous and woody plants (Harper et al, 1965; Beatty, 1984; Hartgerink and Bazzaz, 1984; Fowler, 1986; Molofsky and Augspurger, 1992). Because alluvial sites are characteristically diverse in edaphic, hydrologic, and biologic structure, several microsite types, which could potentially influence seedling establishment and growth, can be identified in forested wetland communities (Marks and Harcombe, 1981; Huenneke and Sharitz, 1986, 1990).

Floodplains have little relief, but even slight elevational changes can affect vegetational cover (Tanner, 1986). Overcup oak (Quercus lyrata Walt), swamp laurel oak ( $Q$ laurifolia Michx), willow oak ( $Q$ phellos $L$ ), and water oak ( $Q$ nigra $L$ ) have been observed to occupy different topographical microsites within floodplains of the southern United States. Q lyrata, a member of the subgenus Leucobalanus, grows on temporal sloughs or low flats in the floodplain (Hodges and Switzer, 1979; Tanner, 1986). These sites are frequently flooded, can remain saturated into the growing season, and exhibit poor internal soil aeration (Putnam et al, 1960). Q lyrata has been classified as the most flood-tolerant of the southern United States oaks (McKnight et al, 1981). $Q$ laurifolia is found on low flats near the periphery of temporal sloughs, and is among the most flood-tolerant of oaks in the subgenus Erythrobalanus (Putnam et al, 1960; Hodges and Switzer, 1979; McKnight et al, 1981). Q phellos, subgenus Erythrobalanus, is typically found on low flats, but at a slightly higher elevation than $Q$ laurifolia. It is classified as more flood-tolerant than $Q$ nigra (Putnam et al, 1960; Tanner, 1986). $Q$ nigra, the least flood-tolerant of these Erythrobalanus oaks, grows primarily on high flats or low ridges which are the least frequently flooded positions in the floodplain (Hodges and Switzer, 1979; Tanner 1986). Soils on these sites are saturated for short periods and have the best internal aeration (Putnam et al, 1960).

Woody plants established on a floodplain must survive periodic root inundation by floodwater. Since oxygen is limiting in saturated soil (Ponnamperuma, 1984), terrestrial plants of wetlands must possess the ability to cope or adjust to an anaerobic rhizosphere. The observed stratification of oaks in bottomlands, and the apparent association of flood frequency, duration, and soil aeration along the topographical gradient has prompted this investigation of the ecophysiological mechanisms influencing resistance to root hypoxia by floodplain tree regeneration in the genus Quercus. This paper reports on two experiments conducted to test the hypothesis that bottomland oak species exhibit different resistances to root hypoxia. The thought is that the species which occupy the lowest sites, those sites which have aerobic soil for the shortest duration in the growing season, will demonstrate the greatest resistance to root hypoxia. The hypothesis was tested on seedlings during the establishment phase in Experiment 1, and it was tested on seedlings late in their first growing season in Experiment 2.

\section{MATERIALS AND METHODS}

\section{Experiment 1}

Stratified $Q$ lyrata, $Q$ laurifolia, $Q$ phellos, and $Q$ nigra acorns were sown $2.5 \mathrm{~cm}$ deep in 164 $\mathrm{cm}^{3}$ tubes containing sand. The tubes were placed in a germinator programmed for $8 \mathrm{~h}$ of light at $30^{\circ} \mathrm{C}$ and $16 \mathrm{~h}$ of darkness at $20^{\circ} \mathrm{C}$ (Bonner and Vozzo, 1987). Sand was kept moist to 
facilitate acorn germination. At epicotyl emergence, seedlings were transferred to a hydroponic network in a greenhouse where they were established in a 0.1 strength Hoagland \#2 nutrient solution ( $\mathrm{pH}=5.5$ ) (Jones, 1983).

The hydroponic network, built after a system described by Topa and McLeod (1986), consisted of two $208 \mathrm{~L}$ nutrient solution reservoirs, thirty $18.9 \mathrm{~L}$ plastic pots, and appropriate plumbing. Each pot received non-circulating nutrient solution so that $3.8 \mathrm{~L}$ of solution was replaced every $24 \mathrm{~h}$. Nutrient solution in each pot was bubbled with either $\mathrm{O}_{2}$ or $\mathrm{N}_{2}$ depending on treatment assignment (Topa and McLeod, 1986). $\mathrm{N}_{2}$ was used to maintain dissolved oxygen (DO) concentration at $<0.2 \mathrm{mg} \mathrm{L}^{-1}$ for pots designated to receive the hypoxic rhizosphere treatment. $\mathrm{O}_{2}$ was used to maintain solution DO concentration at $>15 \mathrm{mg} \mathrm{L}^{-1}$ for pots receiving the normoxic rhizosphere treatment. $\mathrm{O}_{2}$ was used rather than air to ensure a homogeneously aerobic rhizosphere.

Four seedlings, one of each species, in the stage of epicotyl emergence were randomly assigned to each of 30 pots. Plants were maintained in nutrient solution for 54 days with half of the pots receiving hypoxic nutrient solution, and the other half receiving normoxic nutrient solution. At d6 of this experiment it was determined that seedlings receiving the hypoxic nutrient solution would all soon die. Shoots were withering and roots had not grown, so these seedlings were given a 24 day recovery period of normoxic nutrient solution. After leaves developed during the recovery period, seedlings once again received hypoxic nutrient solution for the remainder of the experiment.

On each of 3 days near the end of the 54 day experiment, leaf gas exchange variables were measured on three seedlings of each species and treatment. On each seedling, one median leaf in a lag-stage flush was selected for measurement (Hanson et al, 1986). A LCA-3 $\mathrm{CO}_{2}$ analyzer (The Analytical Development Co Ltd, UK) was used to measure $\mathrm{CO}_{2}$ exchange rates and determine intercellular $\mathrm{CO}_{2}$ on these leaves under saturating light $\left(\geq 800 \mu \mathrm{mol} \mathrm{m} \mathrm{m}^{-2} \mathrm{~s}^{-1}\right.$ photosynthetically active photon flux density (PPFD) (Gardiner and Hodges, unpublished). Supplemental light was provided with a fan-cooled, high pressure sodium lamp when ambient light was not saturating. Transpiration and stomatal conductance for these same leaves were measured with a Li-1600 Steady State Porometer (Licor Inc, Lincoln, NE, USA). All gas exchange measure- ments were taken randomly for species and treatment combinations between 1000 and 1200 hours on each sample day. At the end of the experiment, leaf samples for carbon isotope analysis were secured from five randomly chosen pots in each treatment. Dried leaf material was ground to pass \#40 mesh, and analyzed for stable carbon isotope ratios at the Bioscience Laboratory, University of Utah, USA. Leaf tissue was analyzed for stable isotope ratios because we thought this variable would serve as an integrated index of stomatal aperature during rhizosphere hypoxia.

After the 54 day experiment, all 120 seedlings were harvested and dissected into leaves, stems and roots. These dried biomass components were used as indices of proportional biomass accumulation, leaf weight ratio $($ LWR $)=$ leaf weight /total plant weight, stem weight ratio $(S W R)=$ stem weight/total plant weight, root weight ratio $($ RWR $)=$ root system weight/total plant weight, $\mathrm{root} / \mathrm{stem}$ ratio $(\mathrm{R} / \mathrm{S}$ ratio $)=$ root system weight/stem weight. Relative height and diameter growth were calculated from initial and final stem heights and diameters.

\section{Experiment 2}

Stratified acorns from $Q$ lyrata, $Q$ laurifolia, $Q$ phellos and $Q$ nigra were planted in $0.9 \mathrm{~L}$ containers of a $50 \%$ potting soil: $50 \%$ sand mixture (v:v). Containers were placed in a greenhouse where seedlings were grown for about 4 months. Randomly selected lag-stage seedlings were removed from their original containers, soil was carefully washed away from roots, and these seedlings were immediately transferred to a hydroponic network. Four seedlings, one of each species, were randomly assigned to one of 40 pots in the hydroponic network. The network and nutrient solution were the same as those described in Experiment 1. After 2 weeks of seedling acclimation, 20 pots were randomly assigned a 35 day treatment of hypoxic nutrient solution, and 20 pots were maintained in normoxic nutrient solution as a control.

Stomatal conductance and transpiration were measured 3 days before the treatment and on days $1-10,15,20,25,30$, and 35 of the treatment. These variables were measured on one fully expanded leaf from four seedlings in the same morphological stage while a portable lamp maintained PPFD on the leaf between 400 and $800 \mu \mathrm{mol} \mathrm{m}-2 \mathrm{~s}^{-1}$. Stomatal conductance and 
transpiration were measured randomly for species and treatment combinations between 0900 and 1100 hours on each sample day. Diurnal stomatal conductance and transpiration measurements were randomly taken for each treatment and species combination at $2 \mathrm{~h}$ intervals beginning at 0600 hours, and finishing at 2000 hours on 4 days during the last week of the experiment. On each selected seedling, one fully expanded leaf on a predetermined flush was measured under ambient light.

Following the experiment, 15 seedlings in each treatment and species combination were harvested and dissected into leaves, stems, and roots. LWR, SWR, RWR, and $R / S$ ratios were calculated from the dried biomass components. Relative height and diameter growth were calculated from stem heights and diameters measured on days 1 and 35 .

For both experiments, data were analyzed according to a split-plot design with Statistical Analysis System software (SAS Version 6.04, SAS Institute, Cary, NC, USA). DO level was the whole plot and species were the split-plot. If the treatment $x$ species interaction term was significant at $\alpha=0.05$, treatment combination means were separated with a LSD computed for the difference between two whole plot means at the same or different levels of the split-plot mean (Petersen, 1985). If the treatment $x$ species interaction term was not significant, it was pooled into the error term to test significance of the treatment effect.

\section{RESULTS}

\section{Experiment 1}

Net photosynthesis and transpiration were reduced by 78 and $86 \%$, respectively, on plants established in hypoxic nutrient solution (table I). Decline in net photosynthesis and transpiration can be attributed to partial stomatal closure, because stomatal conductance decreased $84 \%$ for plants established in hypoxic nutrient solution (table I). In this experiment, leaf gas exchange did not vary by species under rhizosphere hypoxia. The $\delta^{13} \mathrm{C}$ for plants established in hypoxic nutrient solution averaged about $1 \%$ below that of plants established in hypoxic nutrient solution (table I). Calculated ratios of net photosynthesis/intercellular $\mathrm{CO}_{2}$ were greatest for all oak seedlings established in normoxic nutrient solution, and averaged about $81 \%$ less for seedlings established in hypoxic nutrient solution (table I).

Total plant biomass of seedlings established in hypoxic nutrient solution was $40 \%$ less than that of seedlings established in normoxic nutrient solution. Biomass accumulation decreased $22 \%$ in leaves, $21 \%$ in stems, and $61 \%$ in roots for all oak species. In addition to the depressed biomass accumulation, proportional biomass accumulation in plant components shifted for seedlings established in hypoxic nutrient solution (table II).

For all oaks, roots comprised about $38 \%$ of total plant biomass, but establishment in hypoxic nutrient solution reduced RWRs by $36 \%$ (table II). Therefore, seedling establishment in hypoxic nutrient solution increased proportional biomass accumulation in shoots, but relative change in SWR and LWR differed by species (table II). $Q$ nigra showed an increase in LWR when established in hypoxic nutrient solution, but the other species showed an increase in LWR and SWR. When established in hypoxic nutrient solution, $Q$ nigra and $Q$ phellos maintained proportionately more leaf biomass than $Q$ laurifolia and $Q$ lyrata (table II). But $Q$ lyrata and $Q$ laurifolia maintained proportionately more stem biomass than $Q$ phellos and $Q$ nigra seedlings under rhizosphere hypoxia (table II). R/S ratios of all species decreased about $44 \%$ when established in hypoxic nutrient solution (table II). Though total plant weight differed between rhizosphere treatments, $\mathrm{R} / \mathrm{S}$ ratio was weakly correlated with total plant biomass (correlation coefficient $=0.24$ ).

Relative height growth of seedlings established in normoxic nutrient solution was $72 \%$ greater than relative height growth 
Table 1. Mean net photosynthesis, transpiration, stomatal conductance, stable carbon isotope ratios and net photosynthesis/intercellular $\mathrm{CO}_{2}$ ratios for four bottomland oak species established in normoxic or hypoxic nutrient solution ( $n=9, n=5$ for stable carbon isotope ratio).

\section{Species}

Net photosynthesis $\left(\mu \mathrm{mol} \mathrm{m} \mathrm{m}^{-2} \mathrm{~s}^{-1}\right)$ b

\section{Q lyrata \\ Q laurifolia \\ $Q$ phellos \\ $Q$ nigra}

Treatment mean

Transpiration $\left(\mu \mathrm{g} \mathrm{cm}^{-2} \mathrm{~s}^{-1}\right) \mathrm{c}$

\section{Q lyrata \\ $Q$ laurifolia \\ $Q$ phellos \\ $Q$ nigra}

Treatment mean

Stomatal conductance $\left(\mathrm{cm} \mathrm{s}^{-1}\right)^{d}$

\section{Q lyrata \\ $Q$ laurifolia \\ $Q$ phellos \\ $Q$ nigra}

Treatment mean

Stable carbon isotope ratio $\left(\delta^{13} \mathrm{C} \%\right)^{\text {e }}$

$$
\text { Normoxic mean } \pm S E \text { a }
$$

$$
\text { Hypoxic mean } \pm S E \text { a }
$$

$$
\begin{aligned}
& 2.28 \pm 0.89 \\
& 3.04 \pm 0.92 \\
& 1.29 \pm 0.58 \\
& 1.63 \pm 0.53 \\
& 2.06 \pm 0.38 B
\end{aligned}
$$

$0.05 \pm 0.29$

$0.55 \pm 0.16$

$0.54 \pm 0.24$

$0.33 \pm 0.11$

$0.37 \pm 0.08 \mathrm{~B}$
$0.35 \pm 0.05$
$0.01 \pm 0.00$
$0.32 \pm 0.03$
$0.08 \pm 0.02$
$0.30 \pm 0.04$
$0.06 \pm 0.03$
$0.28 \pm 0.03$
$0.04 \pm 0.01$
$0.32 \pm 0.02^{\mathrm{A}}$
$0.05 \pm 0.01 B$

\section{Q lyrata \\ $Q$ laurifolia \\ $Q$ phellos \\ $Q$ nigra}

Treatment mean

$\begin{array}{ll}-26.6 \pm 0.3 & -27.5 \pm 0.3 \\ -26.8 \pm 0.2 & -27.9 \pm 0.5 \\ -26.8 \pm 0.3 & -28.0 \pm 0.4 \\ -26.4 \pm 0.3 & -26.9 \pm 0.2 \\ -26.6 \pm 0.1 \mathrm{~A} & -27.6 \pm 0 . \mathrm{B}^{\mathrm{B}}\end{array}$

Net photosynthesis/Intercellular $\mathrm{CO}_{2}\left(\mu \mathrm{mol} \mathrm{m} \mathrm{m}^{-2} \mathrm{~s}^{-1}\right)^{\mathrm{f}}$
Q lyrata
$38.1 \pm 4.3$
$7.9 \pm 3.0$
$45.2 \pm 4.5$
$10.9 \pm 3.2$
$Q$ laurifolia
$39.7 \pm 4.3$
$4.3 \pm 1.9$
$Q$ nigra
$33.6 \pm 3.9$
$5.8 \pm 1.9$
Treatment mean
$39.1 \pm 2.2 \mathrm{~A}$
$7.2 \pm 1.3 \mathrm{~B}$

\footnotetext{
a Where treatment $x$ species interactions are significant, treatment combination means followed by the same letter are not different. Treatment means followed by the same letter in a row are not different. ${ }^{b}$ Treatment $x$ species $P>F=$ 0.4373, Treatment $P>F=0.0459$. c Treatment x species $P>F=0.6256$, Treatment $P>F=0.0522$. d Treatment $\mathrm{x}$ species $P>F=0.3215$, Treatment $P>F=0.0015$. e Treatment $x$ species $P>F=0.7037$, Treatment $P>F=0.0181$. f Treatment $\times$ species $P>F=0.6629$; Treatment $P>F=0.0228$.
} 
Table II. Mean biomass weight ratios of plant components for seedlings of four bottomland oak species established in normoxic or hypoxic nutrient solution $(n=15)$.

Species $\quad$ Normoxic mean $\pm S E$ a $\quad H y p o x i c$ mean $\pm S E$ a

Leaf weight ratio $b$

$\begin{array}{lll}\text { Q lyrata } & 0.30 \pm 0.02 \mathrm{E} & 0.37 \pm 0.02 \mathrm{CD} \\ \text { Q laurifolia } & 0.32 \pm 0.02 \mathrm{E} & 0.39 \pm 0.01 \mathrm{C} \\ \text { Q phellos } & 0.34 \pm 0.02 \mathrm{DE} & 0.49 \pm 0.01 \mathrm{~B} \\ \text { Q nigra } & 0.39 \pm 0.02 \mathrm{C} & 0.54 \pm 0.01 \mathrm{~A} \\ \text { Treatment mean } & 0.34 \pm 0.01 & 0.45 \pm 0.01\end{array}$

Stem weight ratio ${ }^{\circ}$

$\begin{array}{lll}\text { Q lyrata } & 0.24 \pm 0.02 \mathrm{~B} & 0.29 \pm 0.01 \mathrm{~A} \\ \text { Q laurifolia } & 0.22 \pm 0.01 \mathrm{BC} & 0.29 \pm 0.01 \mathrm{~A} \\ \text { Q phellos } & 0.20 \pm 0.01 \mathrm{C} & 0.24 \pm 0.01 \mathrm{~B} \\ Q \text { nigra } & 0.15 \pm 0.01 \mathrm{D} & 0.16 \pm 0.01 \mathrm{D} \\ \text { Treatment mean } & 0.20 \pm 0.01 & 0.25 \pm 0.01\end{array}$

Root weight ratio d

$\begin{array}{lll}\text { Q lyrata } & 0.45 \pm 0.04 & 0.33 \pm 0.02 \\ \text { Q laurifolia } & 0.45 \pm 0.02 & 0.30 \pm 0.01 \\ \text { Q phellos } & 0.45 \pm 0.02 & 0.26 \pm 0.01 \\ Q \text { nigra } & 0.45 \pm 0.02 & 0.30 \pm 0.01 \\ \text { Treatment mean } & 0.45 \pm 0.01^{\mathrm{A}} & 0.29 \pm 0.01 \mathrm{~B}\end{array}$

Root/stem ratio $e$

$\begin{array}{lll}\text { Q lyrata } & 2.17 \pm 0.38 & 1.23 \pm 0.16 \\ \text { Q laurifolia } & 2.14 \pm 0.17 & 1.04 \pm 0.08 \\ \text { Q phellos } & 2.30 \pm 0.14 & 1.15 \pm 0.09 \\ \text { Q nigra } & 3.14 \pm 0.18 & 2.16 \pm 0.24 \\ \text { Treatment mean } & 2.46 \pm 0.12 \mathrm{~A} & 1.37 \pm 0.09 \mathrm{~B}\end{array}$

a Where treatments $x$ species interactions are significant, treatment combination means followed by the same letter are not different. Treatment means followed by the same letter in a row are not different. $b$ Treatment $x$ species $P>$ $F=0.0386 .^{c}$ Treatment $x$ species $P>F=0.0204$. ${ }^{d}$ Treatment $x$ species $P>F=0.3075$, treatment $P>F=0.0001$. e Treatment $\mathrm{x}$ species $P>F=0.8071$, treatment $P>F=0.0001$.

of seedlings established in hypoxic nutrient solution. Seedlings established in normoxic nutrient solution grew $131 \%$ larger in diameter than seedlings established in hypoxic nutrient solution. However, neither relative height growth or relative diameter growth varied by species when established in hypoxic nutrient solution.

\section{Experiment 2}

For all species, rhizosphere hypoxia reduced stomatal conductance below that of control seedlings by $\mathrm{d} 3$ of the treatment (fig 1). From d3 through termination of the experiment, stomatal conductance of stressed seedlings remained lower than 
Fig 1. (A) Mean stomatal conductance \pm standard error for four species of bottomland oak seedlings 3 days before treatment and during 35 days of rhizosphere hypoxia. Significant differences $(\alpha=0.05)$ between seedlings in normoxic ( $\square$ ) and hypoxic ( $\square$ ) nutrient solution are noted by an asterisk above the $x$-axis $(n=16)$. Photosynthetically active photon flux density (B) and relative humidity (C) during transpiration and stomatal conductance sample periods.

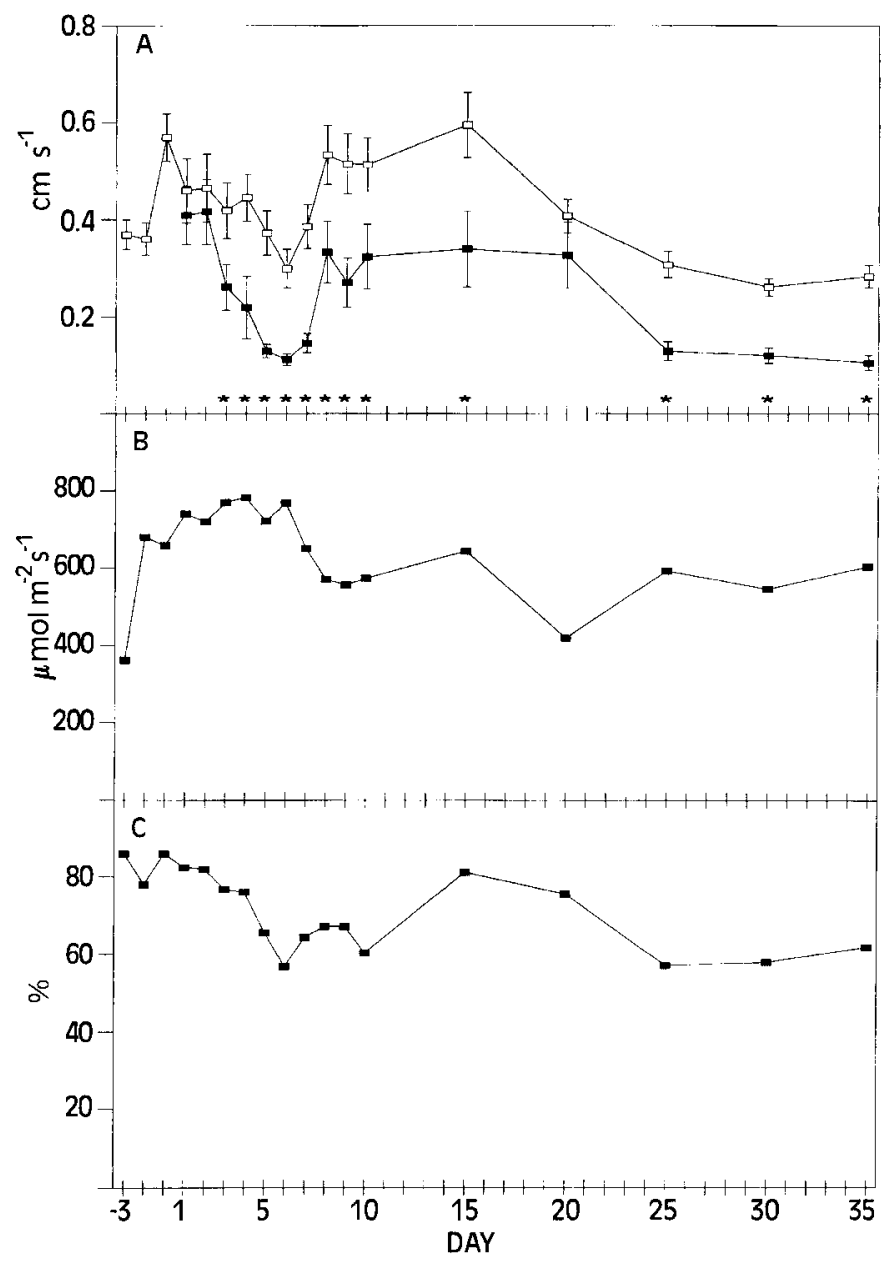

control seedlings, except for d20. On d20, high relative humidity in conjunction with low PAR probably reduced the treatment's effect on stomatal conductance (fig 1). Significant treatment $x$ species interactions on $\mathrm{d} 5$, and $\mathrm{d} 7 \mathrm{-d} 10$ indicated stomatal conductance of stressed seedlings differed by species. During this time, $Q$ lyrata stomatal conductance was not reduced by rhizosphere hypoxia. On d5 and $\mathrm{d7}, \mathrm{Q}$ laurifolia stomatal conductance was lower on plants in hypoxic nutrient solution. Between d5 and d10, stomatal conductance for $Q$ phellos and $Q$ nigra seedlings in hypoxic nutrient solution averaged $35 \%$ lower than seedlings in normoxic nutrient solution. Observed reductions in transpiration resulting from rhizosphere hypoxia generally paralleled declines in stomatal conductance. On 12 of the 15 sample days, seedlings growing in hypoxic nutrient solution maintained lower transpiration rates than control seedlings. Similar to stomatal conductance, transpiration rates on $d 5$, and d7-d10 varied by species. 
Diurnal patterns of stomatal conductance were similar for all species, but magnitude differed by DO treatment (fig 2). Stomatal conductance of control seedlings increased to $0.26 \pm 0.02 \mathrm{~cm} \mathrm{~s}^{-1}$ at 1000 hours, decreased around midday, and slightly increased at 1600 hours before falling at night (fig 2). Stomatal conductance was greatest on stressed seedlings at 1000 hours when it averaged $0.13 \pm 0.02 \mathrm{~cm} \mathrm{~s}^{-1}$. At the 0800 hours sample period, stomatal conductance of $Q$ laurifolia, $Q$ phellos, and $Q$ nigra seedlings growing in hypoxic nutri- ent solution showed lower rates than control seedlings. However, stomatal conductance of $Q$ lyrata was not influenced by the treatment at this sample time. For all species, stomatal conductance during the 'midday slump' was $85 \%$ of the maximum conductance rate in control seedlings, but it was $77 \%$ of the maximum conductance rate in stressed plants. Diurnal patterns of transpiration paralleled those of stomatal conductance.

For these older seedlings, roots were the only plant component in which biomass

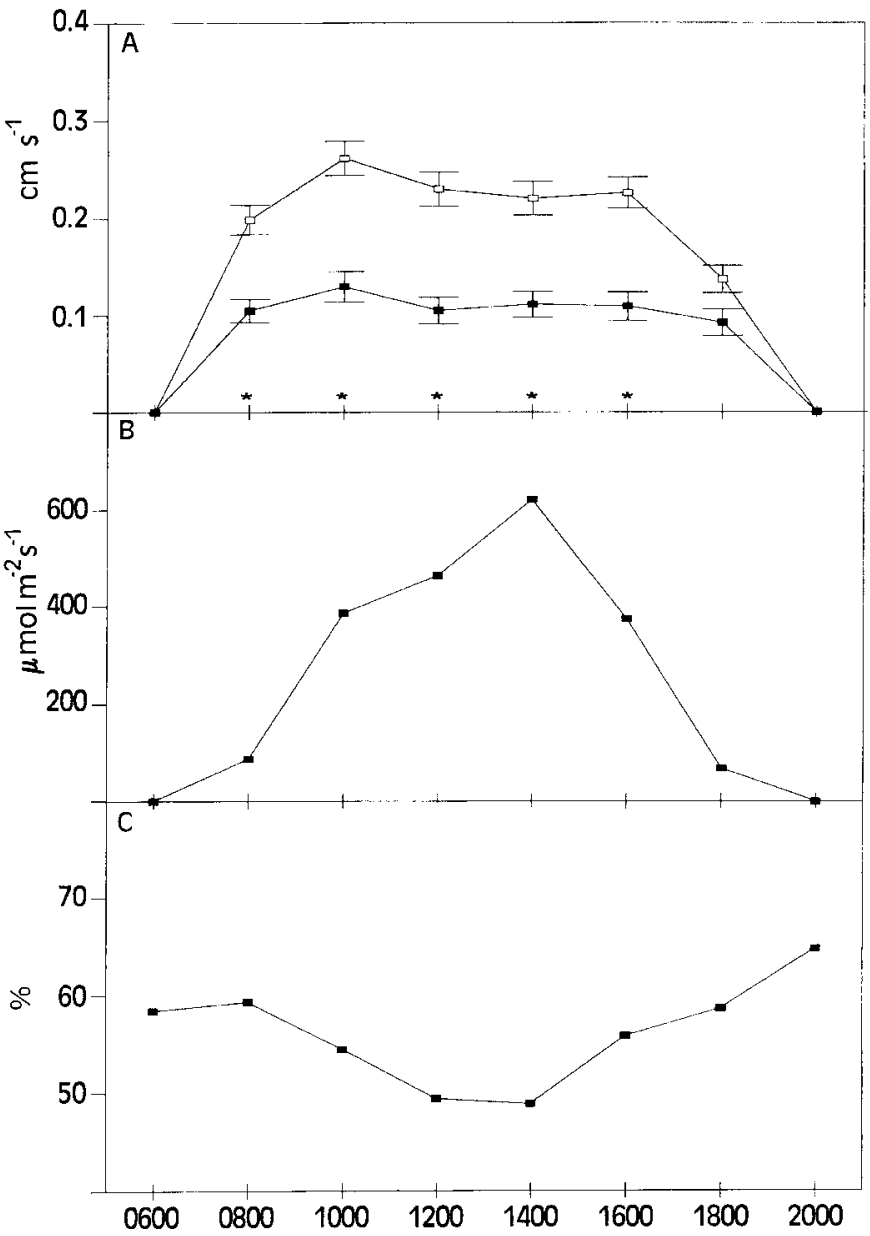

Fig 2. (A) Mean diurnal stomatal conductance \pm standard error for four species of bottomland oak seedlings during 35 days of rhizosphere hypoxia. Significant differences $(\alpha=$ 0.05 ) between seedlings in normoxic ( $\square$ ) and hypoxic (ם) nutrient solution are noted by an asterisk above the $x$-axis $(n=16)$. Photosynthetically active photon flux density (B) and relative humidity (C) during transpiration and stomatal conductance sample periods. 
accumulation was significantly reduced by 35 days of rhizosphere hypoxia. Root systems grown in normoxic nutrient solution averaged $47 \%$ more biomass than those grown in hypoxic nutrient solution (data not shown). In spite of the decrease in root biomass accumulation, total plant biomass accumulation was not changed by 35 days of rhizosphere hypoxia. However, shifts in proportional biomass accumulation were found after 35 days of rhizosphere hypoxia.

LWRs varied by species within nutrient solution type (table III). $Q$ lyrata and $Q$ nigra seedlings grown in hypoxic nutrient solution had proportionally more leaf biomass than plants grown in normoxic nutrient solu-

Table III. Mean biomass weight ratios of plant components for seedlings of four bottomland oak species grown in normoxic or hypoxic nutrient solution for 35 days $(n=15)$.

Species

Leaf weight ratio $b$

\section{Q lyrata \\ Q laurifolia \\ $Q$ phellos \\ $Q$ nigra}

Treatment mean

Stem weight ratio ${ }^{c}$

\section{$Q$ lyrata \\ $Q$ laurifolia \\ $Q$ phellos \\ $Q$ nigra}

Treatment mean

Root weight ratio ${ }^{d}$

$Q$ lyrata

$Q$ laurifolia

$Q$ phellos

$Q$ nigra

Treatment mean

Root/stem ratio ${ }^{e}$

Q lyrata
Q laurifolia
$Q$ phellos
$Q$ nigra

Treatment mean
Normoxic mean $\pm s e^{a}$

Hypoxic mean \pm se a
$0.18 \pm 0.01 \mathrm{E}$
$0.23 \pm 0.02 \mathrm{D}$
$0.32 \pm 0.02 \mathrm{C}$
$0.38 \pm 0.02^{8}$
$0.24 \pm 0.02 \mathrm{D}$
$0.26 \pm 0.01 \mathrm{D}$
$0.42 \pm 0.02 \mathrm{~A}$
$0.27 \pm 0.01$
$0.29 \pm 0.01$
$0.19 \pm 0.01$
$0.26 \pm 0.02$
$0.22 \pm 0.01$
$0.18 \pm 0.01$
$0.32 \pm 0.02$
$0.25 \pm 0.02$
$0.14 \pm 0.01$
$0.21 \pm 0.01$
$0.18 \pm 0.01 \mathrm{~B}$
$0.26 \pm 0.01 \mathrm{~A}$

$0.63 \pm 0.01^{\mathrm{A}}$

$0.49 \pm 0.02 \mathrm{CD}$

$0.55 \pm 0.02 \mathrm{~B}$

$0.43 \pm 0.03 \mathrm{D}$

$0.51 \pm 0.02 \mathrm{BC}$

$0.48 \pm 0.02 \mathrm{CD}$

$0.48 \pm 0.02 \mathrm{CD}$

$0.37 \pm 0.03 \mathrm{E}$

$0.54 \pm 0.01$

$0.44 \pm 0.01$

$\begin{array}{ll}3.40 \pm 0.22 & 2.03 \pm 0.19 \\ 2.68 \pm 0.22 & 1.44 \pm 0.15 \\ 3.03 \pm 0.25 & 2.16 \pm 0.27 \\ 3.60 \pm 0.33 \mathrm{~A} & 1.99 \pm 0.34 \mathrm{~B} \\ 3.17 \pm 0.13 \mathrm{~A} & 1.90 \pm 0.13 \mathrm{~B}\end{array}$

\footnotetext{
a Where treatment $x$ species interactions are significant, treatment combination means followed by the same letter are not different. Treatment means followed by the same letter in a row are not different. $b$ Treatment $x$ species $P>F=0.0003$. c Treatment $\times$ species $P>F=0.3710$, Treatment $P>F=0.0001$. ${ }^{d}$ Treatment $\times$ species $P>F=$ 0.0196. e Treatment $\times$ species $P>F=0.4258$, Treatment $P>F=0.001$
} 
tion (table III). LWR for $Q$ laurifolia was not changed by rhizosphere hypoxia, but the LWR of $Q$ phellos declined $19 \%$ in hypoxic nutrient solution. $Q$ nigra showed the greatest LWR in both nutrient solutions (table III). For all oaks, SWR increased 44\% under 35 days of rhizosphere hypoxia (table III). For three of four oak species, RWR decreased during 35 days of rhizosphere hypoxia (table III). This shift placed $Q$ nigra below the other three species in terms of the proportion of root biomass maintained under rhizosphere hypoxia. For all species, R/S ratios were $40 \%$ lower when seedlings were raised in hypoxic nutrient solution (table III). In this experiment, two lines of evidence indicate differences in $\mathrm{R} / \mathrm{S}$ ratios were allocation responses rather than a function of total plant biomass. First, total plant biomass did not differ between plants grown in hypoxic and normoxic nutrient solution. And, the correlation between $\mathrm{R} / \mathrm{S}$ ratio and total plant biomass was very low (correlation coefficient $=-0.30$ ).

Relative height and diameter growth for seedlings grown in hypoxic nutrient solu- tion differed by species (table IV). $Q$ lyrata relative height growth was small and did not differ in response to rhizosphere hypoxia. The lack of growth in this species may relate to its late-season phenology. Among the Erythrobalanus species, $Q$ laurifolia grew equally well in either solution. However, $Q$ phellos and $Q$ nigra seedlings in hypoxic solution attained only $30 \%$ of the relative height growth of seedlings in normoxic solution (table IV). Under rhizosphere hypoxia, average $Q$ lyrata diameter growth was over 3.5 times larger than for seedlings grown in normoxic solutions (table IV). $Q$ laurifolia seedlings in hypoxic solutions grew over 1.8 times larger in diameter than seedlings in normoxic solutions (table IV). Thirty-five days of rhizosphere hypoxia did not change relative diameter growth for $Q$ phellos and $Q$ nigra seedlings (table IV).

\section{DISCUSSION AND CONCLUSIONS}

Short-term photosynthetic decline for plants growing in saturated soil is often ascribed to

Table IV. Mean relative height and diameter growth for seedlings of four bottomland oak species grown in normoxic or hypoxic nutrient solution for 35 days $(n=20)$.

Species Normoxic mean $\pm S E$ a $\quad H y p o x i c$ mean $\pm S E$ a

Relative height growth (\%) b

Q lyrata

$Q$ laurifolia

Q phellos

$Q$ nigra

Relative diameter growth (\%)

Q lyrata

$Q$ laurifolia

Qphellos

Q nigra
$0.1 \pm 0.1 \mathrm{C}$
$21.3 \pm 6.5 \mathrm{~B}$
$40.8 \pm 7.7 \mathrm{~A}$
$37.5 \pm 6.6^{\mathrm{A}}$

$7.2 \pm 1.3^{\mathrm{D}}$

$19.2 \pm 1.9 \mathrm{C}$

$24.3 \pm 2.6^{B}$

$28.2 \pm 3.4 \mathrm{AB}$ $\begin{aligned} 2.3 & \pm 0.9 \mathrm{C} \\ 19.9 & \pm 7.7 \mathrm{~B} \\ 11.9 & \pm 3.1 \mathrm{BC} \\ 12.4 & \pm 2.3 \mathrm{BC}\end{aligned}$

$25.8 \pm 4.9^{B}$

$36.3 \pm 3.1^{\mathrm{A}}$

$24.7 \pm 2.8^{B}$

$22.5 \pm 3.1^{B}$

\footnotetext{
a Treatment combination means followed by the same letter are not different. b Treatment $x$ species $P>F=0.0034$.

c Treatment $x$ species $P>F=0.001$.
} 
partial closure of stomates (Peterson and Bazzaz, 1984; Pezeshki and Chambers, 1985a, b; Tsukahara and Kozlowski, 1986). Stomatal closure can reduce net photosynthesis by limiting the intercellular $\mathrm{CO}_{2}$ concentration available for assimilation (Kozlowski and Pallardy, 1984). In Experiment 1 , significant decline in net photosynthesis was observed concomitant to reduced stomatal aperture. However, nonstomatal limitations to photosynthesis may also be observed after extended periods of root hypoxia (McLeod et al, 1986; Dreyer et al, 1991; Beckman et al, 1992; Vu and Yelenosky, 1992). Kozlowski and Pallardy (1984) suggested that nonstomatal limitation to photosynthesis during soil saturation may include decline in chlorophyll concentration and changes in carboxylation enzymes. In Experiment 1, leaves of plants established under rhizosphere hypoxia appeared more chlorotic than the leaves on plants established in normoxic nutrient solution. Two stronger lines of evidence indicate that nonstomatal mechanisms contributed to limiting net photosynthesis of oaks established in hypoxic nutrient solution. First, ratios of net photosynthesis/intercellular $\mathrm{CO}_{2}$ decreased under rhizosphere hypoxia indicating a decline in assimilated $\mathrm{CO}_{2}$ per unit of available $\mathrm{CO}_{2}$. And, a decrease in $\delta^{13} \mathrm{C}$ was observed on plants established under rhizosphere hypoxia indicating greater enzymatic discrimination against ${ }^{13} \mathrm{C}$. Greatest discrimination would be expected in leaves having the largest $\mathrm{C}_{\mathrm{i}} / \mathrm{C}_{\mathrm{a}}$ ratios (Farquhar et al, 1982). For example, if $\mathrm{CO}_{2}$ assimilation was reduced relatively more than stomatal conductance (Guy and Wample, 1984). In this study, stomatal and possible nonstomatal mechanisms appeared to limit net photosynthesis of oaks established in hypoxic nutrient solution. However, all species showed a similar decrease in net photosynthesis when established in hypoxic nutrient solution.
Partial stomatal closure can also account for decreased transpiration under anaerobic soil conditions, because transpiration is often observed to decline without a concurrent change in leaf water potential (Pezeshki and Chambers, 1986; Osonubi and Osundina, 1987). Quick stomatal response to soil flooding decreased transpiration within 2 days of soil flooding for Q pagoda (Raf), $Q$ michauxii (Nutt), and $Q$ macrocarpa (Michx) (Tang and Kozlowski, 1982b; Pezeshki and Chambers, 1985a, 1986). In Experiment 1, transpiration of seedlings established in hypoxic nutrient solution appeared to be limited primarily by stomatal closure, and it decreased similarly for all species. For the older seedlings, greatest stomatal disfunction was recorded between $\mathrm{d} 5$ and $\mathrm{d} 10$ of the stress. During this period, $Q$ lyrata seedlings were effected the least. $Q$ phellos and $Q$ nigra showed the greatest decline in stomatal function during this period.

Diurnal patterns of stomatal conductance and transpiration observed in the second experiment were in general agreement with published results on other species grown in flooded soil. Stomatal conductance is often reduced during midday, but the degree of reduction is typically greatest in stressed plants (Tang and Kozlowski, 1982a,b). Relative to control plants, seedlings grown in hypoxic nutrient solution exhibited lower stomatal conductance and transpiration rates, and proportionally greater midday fluctuations of these parameters. Treatment effects on $Q$ lyrata stomatal function were realized later in the day than on the other three species.

Rhizosphere hypoxia induced morphological changes in leaves, stems, and roots for seedlings of both age classes. Root hypoxia can stimulate changes in leaf morphology by promoting abscission, reducing expansion rate, or preventing leaf formation (Sena Gomes and Kozlowski, 1980b; 
Smit et al, 1990; Terazawa and Kikuzawa, 1994). Leaf abscission was not observed in either experiment, but LWRs increased for all plants receiving rhizosphere hypoxia. In both experiments, Q lyrata and Q laurifolia maintained the smallest proportion of leaf biomass under rhizosphere hypoxia, while $Q$ nigra maintained the highest LWR under rhizosphere hypoxia.

Stems of seedlings established in hypoxic nutrient solution were $20 \%$ smaller in mass than those of seedlings established in normoxic nutrient solution. Q lyrata and $Q$ laurifolia maintained a larger proportion of stem biomass than $Q$ phellos and $Q$ nigra, when established under rhizosphere hypoxia. SWRs of the older seedlings were similar for all species under rhizosphere hypoxia. Other hardwood mesophytes usually show a reduction in stem dry weight resulting from root hypoxia (Hosner and Boyce, 1962; Dickson et al, 1965; Tang and Kozlowski, 1982b), but 4 months of soil flooding did not change RWR of $Q$ pagoda seedlings (Jones et al, 1989).

Root biomass is often reduced during short-term soil flooding, even on hydric species such as Taxodium distichum $\mathrm{L}$ (McLeod et al, 1986). Roots may show reduced biomass in anaerobic soil because of reduced growth or decomposition (Hook and Brown, 1973; Angeles et al, 1986). In these experiments, evidence of root system decomposition was not visible. So, differences in root biomass accumulation are attributed to root growth differences between treatments. During seedling establishment, RWR was decreased similarly for all species. But in hypoxic nutrient solution, $Q$ nigra maintained the proportionately smallest root system among the older seedlings. Several authors have argued that reduced root growth on seedlings in flooded soil will decrease post-flood drought tolerance of these seedlings (Tang and Kozlowski, 1982a,b; Sena Gomes and Kozlowski 1980b). In this study, decreased root mass and relatively high proportions of leaf mass may predispose $Q$ phellos and $Q$ nigra to slow post-flood recovery.

In both experiments, proportional biomass accumulation was shifted towards the shoot. $R / S$ ratio of plants receiving hypoxic nutrient solution were lower than those of plants receiving normoxic nutrient solution. This occurred apart from decreases in total plant biomass on the stressed seedings. Topa and McLeod (1986) found a similar root-shoot response for conifer seedlings which were grown in anaerobic nutrient solution. In contrast, two Eucalyptus species showed proportionately more root growth than shoot growth, this was primarily a result of adventitious root generation and leaf abscission under conditions of anaerobic soil (Sena Gomes and Kozlowski 1980a).

Soil saturation during the growing season typically reduces shoot growth of older, mesophytic seedlings (Dickson et al, 1965; Gill, 1970; Topa and McLeod, 1986). Though most of the energy and carbon required for initial shoot growth is provided by the acorn (Crow, 1988), rhizosphere hypoxia limited shoot growth of all oaks during seedling establishment (Experiment 1). Thus, a functional root system is required to realize potential shoot growth of seedlings during establishment. For the older seedlings, relative growth responses to rhizosphere hypoxia varied by species. Relative height growth of $Q$ phellos and $Q$ nigra were reduced $69 \%$ in hypoxic nutrient solution. However, $Q$ lyrata and $Q$ laurifolia relative diameter growth increased under rhizosphere hypoxia. Increased diameter growth has been observed on other species grown in flooded soil, and attributed to stem hypertrophy (Yamamoto et al, 1987). In this study, rhizosphere hypoxia may have induced enlargement of the basal portion of stems, but there was not excessive stem hypertrophy as reported for other species subjected to soil flooding (Gardiner, 1994). 
Micromorphological examinations have failed to reveal aerenchyma formation by these and other bottomland oaks of the southern United States (Pezeshki, 1991; Gardiner, 1994).

Results from the first experiment indicated early exposure to hypoxic nutrient solution was equally lethal to all establishing species. However, seedlings allowed to recover demonstrated that shifts in plant morphology may be important for resistance to root hypoxia during seedling establishment. High LWRs along with significant reductions in root mass place $Q$ phellos and $Q$ nigra as the least resistant to root hypoxia during seedling establishment. Species resistance to rhizosphere hypoxia during seedling establishment could not be separated through physiological or growth responses. For the older seedlings, $Q$ lyrata and $Q$ laurifolia showed early physiological resistance, a morphology most conducive to survival under rhizosphere hypoxia, and better shoot growth than $Q$ phellos and $Q$ nigra. These findings do not completely explain bottomland oak distribution in floodplains, and the results may have been different if seedlings were raised in soil rather than nutrient solution. However, these findings indicate that low oxygen partial pressures around roots can influence bottomland oak physiology, morphology and growth. Thus, it potentially plays a strong role in determining establishment, survival and growth of bottomland oak regeneration.

\section{ACKNOWLEDGMENTS}

We thank the many people who assisted with design and implementation of this research. Two anonymous reviewers are thanked for their constructive comments on an earlier draft of this manuscript. This article has been approved for publication as Journal Article No FA-035-0695 of the Forest and Wildlife Research Center, Mississippi State University.

\section{REFERENCES}

Angeles G, Evert RF, Kozlowski TT (1986) Development of lenticels and adventitious roots in flooded Ulmus americana seedlings. Can J For Res 16, 585590

Beatty SW (1984) Influence of microtopography and canopy species on spatial patterns of forest understory plants. Ecology 65, 1406-1419

Beckman TG, Perry RL, Flore JA (1992) Short-term flooding affects gas exchange characteristics of containerized sour cherry trees. Hort Sci27, 1297 1301

Bonner FT, Vozzo JA (1987) Seed biology and technology of Quercus. USDA, Forest Service, Gen Tech Rep SO-66

Crow TR (1988) Reproductive mode and mechanisms for self-replacement of northern red oak (Quercus rubra) - a review. For Sci 34, 19-40

Dickson RE, Hosner JF, Hosley NW (1965) The effects of four water regimes upon the growth of four bottomland tree species. For Sci 11, 299-305

Dreyer $E$, Colin-Belgrand M, Biron P (1991) Photosynthesis and shoot water status of seedlings from different oak species submitted to waterlogging. Ann Sci For 48, 205-214

Farquhar GD, O'Leary MH, Berry JA (1982) On the relationship between carbon isotope discrimination and the intercellular carbon dioxide concentration in leaves. Aust J Plant Physiol 9, 121-137

Fowler NL (1986) Microsite requirements for germination and establishment of three grass species. Am Midl Nat 115, 131-145

Gardiner ES (1994) Physiological responses of four bottomland oak species to root hypoxia. PhD Dissertation, Mississippi State University

Gill CJ (1970) The flooding tolerance of woody species - a review. For Abst 31, 671-688

Guy RD, Wample RL (1984) Stable carbon isotope ratios of flooded and nonflooded sunflowers (Helianthus annuus). Can J Bot 62, 1770-1774

Hanson PJ, Dickson RE, Isebrands JG, Crow TR, Dixon RK (1986) A morphological index of Quercus seedling ontogeny for use in studies of physiology and growth. Tree Physio/ 2, 273-281

Harper JL, Williams JT, Sagar GR (1965) The behaviour of seeds in soil. I. The heterogeneity of soil surfaces and its role in determining the establishment of plants from seed. J Ecol 53, 273-286

Hartgerink AP, Bazzaz FA (1984) Seedling-scale environmental heterogeneity influences individual fitness and population structure. Ecology 65, 198206

Hodges JD, Switzer GL (1979) Some aspects of the ecology of southern bottomland hardwoods. In: North 
America's Forests: Gateway To Opportunity. Proceedings of the 1978 Joint Convention of the Society of American Foresters and the Canadian Institute of Forestry, Society of American Foresters, Washington, DC, 360-365

Hook DD, Brown CL (1973) Root adaptations and relative flood tolerance of five hardwood species. For Sci $19,225-229$

Hosner JF, Boyce SG (1962) Tolerance to water saturated soil of various bottomland hardwoods. For $\mathrm{SCl}$ $8,180-186$

Huenneke LF, Sharitz RR (1986) Microsite abundance and distribution of woody seedlings in a South Carolina cypress-tupelo swamp. Am Midl Nat 115, 328335

Huenneke LF, Sharitz RR (1990) Substrate heterogeneity and regeneration of a swamp tree, Nyssa aquatica. Am J Bot 77, 413-419

Jones JB Jr, (1983) A Guide for the Hydroponic and Soitless Culture Grower. Timber Press, Portland, OR

Jones RH, Sharitz RR, McLeod KW (1989) Effects of flooding and root competition on growth of shaded bottomland hardwood seedlings. Am Midl Nat 121, 165-175

Kozlowski TT, Pallardy SG (1984) Effects of flooding on water, carbohydrate, and mineral relations. In: Flood ing and Plant Growth (TT Kozlowski, ed), Academic Press Inc, Orlando, FL, 165-193

Marks PL, Harcombe PA (1981) Forest vegetation of the Big Thicket, southeast Texas. Ecol Monog 51, 287-305

McKnight JS, Hook DD, Langdon OG, Johnson RL (1981) Flood tolerance and related characteristics of trees of the bottomland forests of the southern United States. In: Wetlands of Bottomland Hard wood Forests (JR Clark, J Benforado, eds), Elsevier Scientific Pub Co, New York, 29-69

McLeod KW, Donovan LA, Stumpff NJ, Sherrod KC (1986) Biomass, photosynthesis and water use efficiency of woody swamp species subjected to flooding and elevated water temperature. Tree Physiol $2,341-346$

Molofsky J, Augspurger CK (1992) The effect of leaf litter on early seedling establishment in a tropical forest. Ecology 73, 68-77

Osonubi O, Osundina MA (1987) Stomatal responses of woody seedlings to flooding in relation to nutrient status in leaves. J Exp Bot 38, 1166-1173

Petersen RG (1985) Design and Analysis of Experiments. Marcell Dekker Inc, New York

Peterson DL, Bazzaz FA (1984) Photosynthetic and growth responses of silver maple (Acer saccharinum L) seedlings to flooding. Am Midl Nat 112, 261-272

Pezeshki SR (1991) Root responses of flood-tolerant and flood-sensitive tree species to soil redox conditions. Trees 5, 180-186
Pezeshki SR, Chambers JL (1985a) Responses of cherrybark oak seedlings to short-term flooding. For Sci 31, 760-771

Pezeshki SR, Chambers JL (1985b) Stomatal and photosynthetic response of sweet gum (Liquidambar styraciffua) to flooding. Can J For Res 15, 371-375

Pezeshki SR, Chambers JL (1986) Variation in floodinduced stomatal and photosynthetic responses of three bottomland tree species. For Sci 32, 914923

Ponnamperuma FN (1984) Effects of flooding on soils. In: Flooding and Plant Growth (TT Kozlowski, ed), Academic Press Inc, Orlando, FL, 9-45

Putnam JA, Furnival GM, McKnight JS (1960) Management and Inventory of Southern Hardwoods. USDA Agricultural Handbook, 181

Sena Gomes AR, Kozlowski TT (1980a) Effects of flooding on Eucalyptus camaldulensis and Eucalyptus globulus seedlings. Oecologia 46,139-142

Sena Gomes AR, Kozlowski TT (1980b) Responses of Pinus halepensis seedlings to flooding. Can J For Res 10, 308-311

Smit BA, Neuman DS, Stachowiak ML (1990) Root hypoxia reduces leaf growth. Plant Physiol 92, 10211028

Tang ZC, Kozlowski TT (1982a) Physiological, morphological, and growth responses of Platanus occidentalis seedlings to flooding. Plant Soil 66, 243255

Tang ZC, Kozlowski TT (1982b) Some physiological and morphological responses of Quercus macrocarpa seedlings to flooding. Can J For Res 12, 196202

Tanner JT (1986) Distribution of tree species in Louisiana bottomland forests. Castanea 51, 168-174

Terazawa K, Kikuzawa K (1994) Effects of flooding on leaf dynamics and other seedling responses in flood-tolerant Alnus japonica and flood-intolerant Betula platyphylla var japonica. Tree Physiol 14, 251-261

Topa MA, McLeod KW (1986) Responses of Pinus clausa, Pinus serotina and Pinus taeda seedlings to anaerobic solution culture. I. Changes in growth and root morphology. Physiol Plant 68, 523-531

Tsukahara H, Kozlowski TT (1986) Effect of flooding and temperature regime on growth and stomatal resistance of Betula platyphylla var japonica seedlings. Plant Soil 92, 103-112

Vu JC, Yelenosky G (1992) Photosynthetic responses of rough lemon and sour orange to soil flooding, chilling, and short-term temperature fluctuations during growth. Environ Exp Bot 32, 471-477

Yamamoto F, Kozlowski TT, Wolter KE (1987) Effect of flooding on growth, stem anatomy, and ethylene production of Pinus halepensis seedlings. Can J For Res 17, 69-79 